\title{
A Review of Energy Modeling Tools for Energy Efficiency in Smart Cities
}

\author{
Fernando Martins (D), Carlos Patrão *(D), Pedro Moura (D) and Aníbal T. de Almeida (D) \\ Institute of Systems and Robotics, Department of Electrical and Computer Engineering, University of Coimbra, \\ 3030-290 Coimbra, Portugal; fmartins@isr.uc.pt (F.M.); pmoura@isr.uc.pt (P.M.); adealmeida@isr.uc.pt (A.T.d.A.) \\ * Correspondence: carlospatrao@isr.uc.pt; Tel.: +351-239-796-201
}

Citation: Martins, F.; Patrão, C.;

Moura, P.; de Almeida, A.T. A Review of Energy Modeling Tools for Energy Efficiency in Smart Cities. Smart Cities 2021, 4, 1420-1436. https://doi.org/ 10.3390/smartcities4040075

Academic Editor: Isam Shahrour

Received: 23 September 2021

Accepted: 14 November 2021

Published: 16 November 2021

Publisher's Note: MDPI stays neutral with regard to jurisdictional claims in published maps and institutional affiliations.

Copyright: (C) 2021 by the authors Licensee MDPI, Basel, Switzerland. This article is an open access article distributed under the terms and conditions of the Creative Commons Attribution (CC BY) license (https:// creativecommons.org/licenses/by/ $4.0 /)$.

\begin{abstract}
Nowadays, modeling tools are a crucial part of best practice in the elaboration and implementation of a decarbonization plan in any organization, city, or country. The present review analyzes the different modeling tools available to assess energy systems in smart cities. It creates an updated overview of the modeling tools currently available, showing their capabilities and main potential outputs when considering the energy efficiency objective in the context of smart cities in Europe. A restricted set of 14 tools are identified which optimally fulfill the modeling mission of the energy sector, in a smart city context, for different time horizons. The selection considers the capability to include decarbonization assessments, namely, by considering the flexibility to use different external factors, energy policies, technologies, and mainly the implementation of Article 7 from the Energy Efficiency Directive and the "energy efficiency first" principle defined by the European Commission. The ELECTRE TRI method was used to implement a multi-criteria decision approach for sorting modeling tools, aiming at distributing the various alternatives by previously defined categories, and considering the performance criteria of each alternative modeling tool, the analysis suggests that the best options are the LEAP, MESSAGEix, and oemof tools.
\end{abstract}

Keywords: modeling tools; smart cities; decarbonization; electrification; energy efficiency

\section{Introduction}

Cities are constantly facing major challenges, mainly due to continuous population growth and their diversion to urban living. These challenges depend on cities' geography and culture but, not exhaustively, are, namely: congestion management, excess pollution, resource usage, absence of satisfactory physical and social infrastructures, necessity to maintain continuous sustainable economic growth, and increasingly narrower energy and environmental obligations [1,2]. The United Nations World Urbanization Prospects [3] state that much more people are living in an urban environment rather than in rural areas, and the dispersion is increasing. About $30 \%$ of the world's population was living in urban areas in 1950. In 2018, this number had increased to 55\%. It is expected an increase to more than $60 \%$ by 2030 [4] and by 2050, the report projections are an increase to about $68 \%$ of the world's population settled in an urban environment [3]. In the United Nations report [3], it is mentioned that this increase in the urban area population is mainly motivated by overall population growth and by their increasing diversion for urban-area living. Collectively, by 2050, the two referred factors could contribute to an increase of about 2.5 billion people living in an urban environment.

Globally, in 2016, there were around 512 urban centers with about 1 million people and about 31 megacities with more than 10 million people [5]. These figures are expected to increase by 2030 to about 662 urban centers and 41 megacities, most of them in developing regions [5]. Therefore, nowadays cities need to be planned to be capable of providing the resources and essential services to ensure meeting the increasing quality of life demands to their populations while at the same time ensuring sustainable development requirements. 
The United Nations Sustainable Development Goals (Ref. [6], with special prominence to SDG 11 [7], together with the New Urban Agenda [8], are catching international recognition to ensure a strong contribution from cities on the road to sustainability, in the pursuit to "Make cities inclusive, safe, resilient and sustainable" [9]. Human life is going through a crucial phase, where efforts to achieve a sustainable balance with the environment are becoming more challenging. A clear example was the agreement reached in the European Parliament to bring the European Union (EU) to climate neutrality, through the approval of the European Climate Law, transforming the political commitment of the European Ecological Pact to bring the EU to climate neutrality by 2050 into a binding obligation, as well as providing European citizens and businesses with the legal certainty and predictability they need to plan their investments during this transition. After the 2050 horizon, the EU's objective will be to achieve negative emissions.

Currently, the generation of electricity is increasingly based on renewable sources, so switching from technologies that use fossil fuels to those that use electricity will generally reduce greenhouse gases (GHG) emissions and the energy dependence of most of the Member States. With the energy transition on the roadmap to a decarbonized economy, the role of electrification is essential, but it can never be implemented effectively, both in terms of costs and timing, without energy efficiency being the priority. A set of opportunities for energy efficiency in buildings, transport, and industries will allow energy savings by switching from inefficient fossil fuel technologies to more efficient electrical technologies. They also provide financial, environmental, health, and property benefits. Therefore, electrification must be seen as an energy efficiency measure if energy savings are achieved. Energy efficiency ensures a key role, not only in global climate change mitigation, but also in increasing the security of energy supply, business competitiveness, and social welfare [10,11].

In this context, the Intergovernmental Panel on Climate Change (IPCC) special report [12] on the impacts of global warming of $1.5^{\circ} \mathrm{C}$ above pre-industrial levels highlighted the end-use energy efficiency and the electrification role for climate mitigation. The International Energy Agency (IEA) also refers to the energy efficiency role as crucial to speed up the necessary clean-energy transition to attain the sustainability and global climate goals [13]. In harmony is also the European Commission, regarding the EU's climate targets that must be supported foremost by the energy-efficiency-first principle [14], at least since the publication of the Council Directive 93/76/EEC of 13 September 1993 to limit carbon dioxide emissions by improving energy efficiency (SAVE), and thus far, with the publication of Directive (EU) 2018/2002, amending Directive 2012/27/EU on energy efficiency (EED) [15], that energy efficiency is part of an ambitious European legislative framework to stimulate the rational use of energy. In Europe, the absence of energy efficiency policies would have contributed to about $12 \%$ higher energy consumption in 2013 [16].

Other EU energy efficiency policies are the Energy Performance of Buildings Directive [17], Ecodesign Directive [18], Energy Labelling Regulation [19], and Regulations for the Reduction of the $\mathrm{CO}_{2}$ Emissions of Vehicles [20]. The Energy Performance of Buildings Directive (EPBD—2010/31/EU) is the main European legislative instrument to promote the energy performance of buildings, regarding energy efficiency and renewable energies national requirements, and requiring Member States to implement an energy labeling system for buildings and define the technical requirements for nearly zero-energy buildings (NZEB). The Ecodesign Directive (2009/125/EC) to improve efficiency in energy-related products currently covers more than 30 product groups. The Energy Labelling Regulation (EU 2017/1369), on the indication by labeling and standard product information of the energy consumption and use of other resources by energy-related products, currently covers 18 different products, and the Regulations for the Reduction of $\mathrm{CO}_{2}$ Emissions of Vehicles (EU 2019/631) sets $\mathrm{CO}_{2}$ emission performance standards for new passenger cars and new vans in the EU.

As Figure 1 shows, the European Union leads the world decarbonization process of the energy sector through a comprehensive legislative framework, which has been designed 
since 2015, providing strategic tools at the Member State level for the creation of the Energy Union, where energy planning is fundamental to fit all initiatives within the scope of energy efficiency, to identify the best way to achieve the national assumed objectives reflected in the Paris Agreement of 2015 [21]. Thus, there is a clear need for a deeper exploration of the role of energy efficiency in energy planning, since the impact is not limited to a decrease in final energy consumption, but also has an impact on the energy supply side, namely, the need for available power for electricity generation (thus contributing to an increase in the share of the final energy consumption that is ensured by renewable sources), the need for investments to reinforce energy transmission and distribution networks, and non-energy impacts, namely, those that promote the improvement of quality of life.

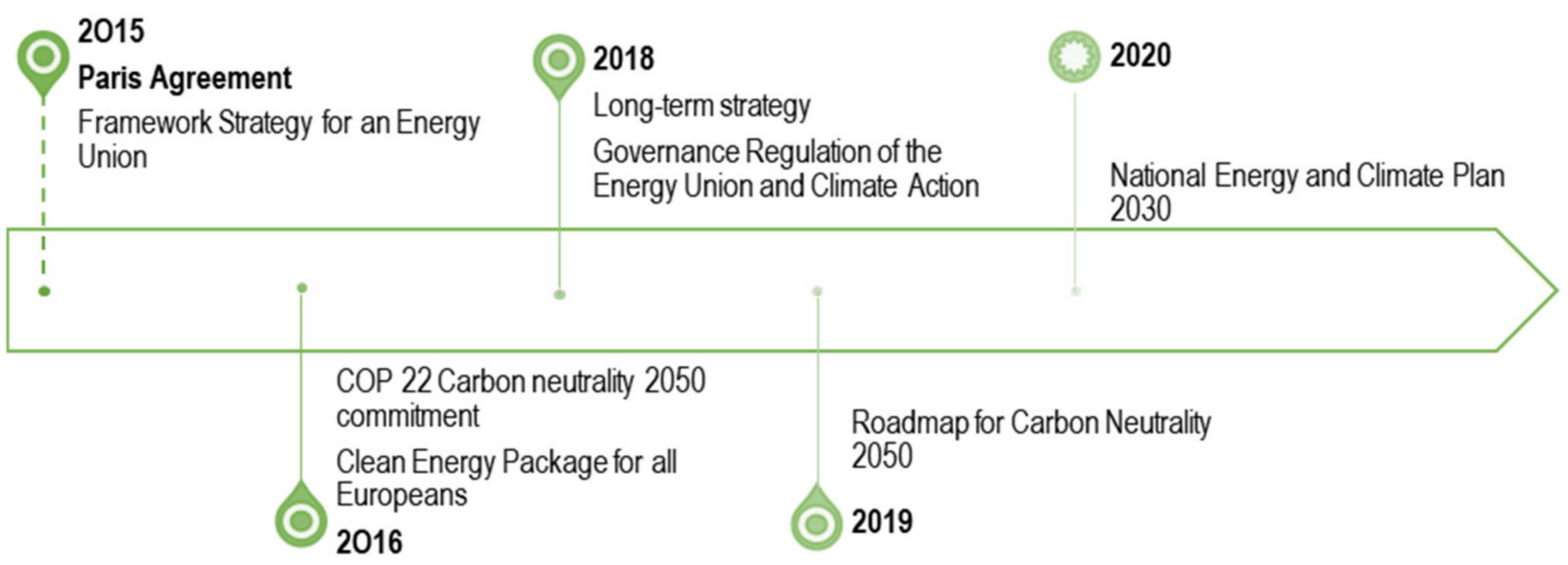

Figure 1. European Union decarbonization legislative framework since 2015.

Electrification is a key tool to change from fossil to decarbonized resources, namely, in the decarbonization of the building and transportation sectors [22]. However, this energy transition process involves a large increase in certain critical mineral needs [23]. In a scenario that meets the goals of the Paris Agreement, the participation of the energy sector in the total consumption of some key minerals increases significantly. Additionally, it is expected that electricity consumption will increase and since, currently, not all electricity generation can be based on renewable energy sources, it will be crucial that today's cities be smart in a short period and ensure efficiency on the final consumption. Therefore, energy efficiency should be the first fuel to be considered in this transition process [24-27].

Based on the above framework, the present study intended to make a review of modeling tools for city energy systems for the energy efficiency objective. The remainder of this paper is structured as follows. Section 2 is dedicated to the "Smart City" concept and the role of energy efficiency. Section 3 describes the methodology adopted to assess the right software tools according to the need to model an energy system considering the energy efficiency objective. Section 4 describes the results of the adopted methodology, and Section 5 presents the main conclusions and future research directions.

\section{Smart City Concept and Energy Efficiency}

The literature presents different terms referring to similar concepts, namely, "Smart City", with "Sustainable City", "Future City", "Green City", "Resilient City", "Eco-City", "Low-carbon City", "Intelligent City", and "Digital City" being the most common [9,28-36]. The use of a combination of terms can also be observed, proposing or defining new concepts, occasionally for demarcation purposes, like, for example, the concept of "Smart Sustainable City" [34,37,38]. It can also be found terms used to highlight distinctive dimensions of their specific assessment such as the "Resilient City" or "Knowledge City" $[9,36]$.

Although sometimes not exactly having the same focus, offering alternative development pathways in response to urban challenges [9], the use of different terms to address 
the "Smart City" concept has been generating terminological misunderstanding [32,39,40]. Nowadays, "Smart City" is probably the most prevalent and acknowledged wording among the majority of citizens, media, investors, companies, and public authorities [41]. Public authorities and the business sector, in general, are using this wording, as it is a buzzword comprehensible by the majority of the targeted stakeholders [34,41].

The increasing interest in "Smart City" and related concept terms are well documented in earlier bibliometric studies, which highlight its growth in scientific publications: Martin de Jong [36] refers to an exponential growth in the use of the "Smart City" term since 2009 when analyzing the period from 1996 to 2013, where "Sustainable City" had about two and a half times more retrieved articles. The same accelerating growth was also demonstrated by Wang [42] when analyzing the articles in the period from 1992 to 2016. In 2021, Schraven [9] extended the search until 2019, which covered the release of the UN's SDGs [6], the New Urban Agenda [8], and other more recent related initiatives. The bibliometric analysis of 35 different concept terms taken from a total of 148 revealed that "Smart City" and "Sustainable City" were the most used terms, with the first overcoming the second since 2012. "Smart City" has undoubtedly become the most investigated concept in recent years, being published in almost half (46\%) of the total number of articles analyzed by Schraven [9] over the last 30 years, apparently due to the increasing adoption of smart technologies (IoT, big data, sensors, smart grids). Schraven [9] also realized that the two most-used terms have a very high level of co-occurrence with each other and significant co-occurrence with other terms, revealing their dominant position and influence, forming two clusters about "Sustainable City" (compact, low-carbon, green, and liveablethe "eco-cluster") and "Smart City" (intelligent, digital, future, ubiquitous, connected, and creative-the "techno-cluster"). Some more recent policy initiatives (e.g., "United for Smart Sustainable Cities" (U4SSC) [43] and the ISO 37122 standard for "Sustainable Cities and Communities-Indicators for Smart Cities" [44]) seem to try to contribute to the combination of the "Sustainable" and "Smart" city concepts, the overall goal of urban development defined in the first and the necessary technological resources to achieve it defined in the second [9].

There are similarities between the concepts of "Sustainable City" and "Smart City", but there are also some significant differences. Studies show that a "Sustainable City" is more focused on environmental and social aspects, while a "Smart City" is mainly focused on the technological, economic, and social aspects [45]. However, despite the low initial weight placed on the importance of environmental factors, the "Smart City" concept seems to be moving towards addressing sustainability issues. Traditionally, the "Smart City" has been interpreted as being more technology-focused instead, rather than the holistic conceptualization. Nevertheless, a holistic view of "Smart City" that includes, among many others, environmental issues is becoming more widespread recently. It is expected that the "Smart City" concept would leverage the technological infrastructure being deployed in an urban environment to deliver key "smart services", such as smart healthcare, smart homes, smart transportation, smart workplaces, smart government, and many others [46]. This perspective is found in academic literature [47-49] and regional or international organizations, such as the European Commission, the IEEE, and the United Nations.

The European Commission (EC) has a vision of smart cities that is beyond the simple use of technology and ICT. The EC points out that smart cities are more about the interaction between all cities' infrastructures with the aim of providing multiple benefits to different sectors. The EC [50] states that smart cities are "Cities using technological solutions to improve the management and efficiency of the urban environment". It refers to the smart city as being " $a$ place where traditional networks and services are made more efficient with the use of digital and telecommunication technologies for the benefit of its inhabitants and business". It is also stated that "a smart city goes beyond the use of information and communication technologies (ICT) for better resource use and fewer emissions. It means smarter urban transport networks, upgraded water supply and waste disposal facilities and more efficient ways to light and heat buildings. It also means a more interactive and responsive city administration, safer public spaces and meeting 
the needs of an aging population" [50]. The IEEE has also a wider perception of the smart city concept in which technology is regarded as an enabler for an improved quality of life and to reduce environmental impacts [45]. The IEEE Smart Cities Initiative [51] states that "a Smart City brings together technology, government and society and includes but is not limited to the following elements: A Smart economy, Smart energy, Smart mobility, Smart environment, Smart living, and Smart governance" [51].

In "Smart Cities and infrastructure report" [52], the United Nations states that there is no standardized, generally recognized definition for the "Smart City" concept. It is although indicated as a reference on the report [52], the definition presented by the International Telecommunication Union (ITU) in 2014, after performing an analysis of about 100 different definitions. This definition was published on the ITU-T Y.4900 recommendations [53], with the following proposal: "an innovative city that uses information and communication technologies (ICTs) and other means to improve quality of life, the efficiency of urban operation and services, and competitiveness, while ensuring that it meets the needs of present and future generations with respect to economic, social, environmental as well as cultural aspects". Even though this definition presented by the ITU [53] is actually for a "Smart Sustainable City", the United Nations uses it as a reference when citing the "Smart City" definition, asserting also that "Governments and stakeholders need to work together to develop a common understanding of what Smart City means in their specific national and city-level contexts" [52]. Currently, the United Nations refers to the "Sustainable Cities and Communities" term as a way to "make cities and human settlements inclusive, safe, resilient and sustainable" [54].

There is a wide variety of respectable studies aiming at the identification of the different dimensions of a "Smart City" [31,31,37,38,48,55-58]. They present different perspectives since the concept of a "Smart City" differs according to the different stakeholders, actors, and viewpoints of the literature [59]. In general, the literature points out the existence of seven main common different dimensions: People, Governance, Environment, Living, Mobility, Data, and Economy [31,37,48,55-65]. One of many common aspects is that energy and energy efficiency is considered one of the many sub-themes, usually inside the "Environment" dimension [48]. Considering all the multi-dimension concepts and all the different indicators inside them, energy efficiency concerns must be, directly or indirectly, taken into account and properly assessed on several of them when implementing a "Smart City" project. To have, for instance, an adequate and sustainable communications network (Data dimension), the efficiency of all the ICT equipment must be taken into account. Energy efficiency has to be considered in all technology-related dimensions, but even in the economy-related indicators, Energy Intensity is taken into account [56], which in some way is also related to energy efficiency. Almost all activities within cities require energy (i.e., transportation, work activities, security, entertainment, commerce, homes, etc.). Therefore, energy efficiency is becoming a crucial challenge for life in cities [66], and for the smart city implementations, that must be properly assessed.

With the increasing deployment of "Smart Cities", various smart city assessment tools with distinct evaluation indicators have been established [41]. These tools use different indicator sets for the overall assessment of a specific dimension of the smart city. Given that energy efficiency is usually integrated into the Environment dimension, it is important to properly evaluate the most adequate city energy systems modeling tools that can be used for a proper indicator calculation.

\section{Methodology}

Given today's importance of the topic, especially due to the elaboration of the National Energy Climate Plans (NECP) in Europe, there was a need to model the energy system of the different Member States (MS) to the horizon of 2030 [67]. For this, it was necessary to model the energy systems of the cities of the future, where all activities must be harmonized, where the energy used will have origins in the usage of endogenous and renewable energy sources, and where consumers should become prosumers, autonomous and managing their consumption in real-time, thus minimizing the costs. On the other hand, the role of 
transport in cities will be fundamental to balance supply and demand, as the contribution of electric vehicles will allow the storage of excess energy produced during off-peak hours to be injected into the grid during periods of the greatest need [68].

The future of the planet depends on the ability of cities to shift towards more sustainable living standards. Cities with new dynamics are needed, capable of generating and consuming energy efficiently and smartly. Cities, as concentrated centers of energy consumers, integrated with a complex ecosystem, are a fundamental component for achieving national goals, hence the importance of modeling the energy systems of the cities of the future, characterized by being more digital and more flexible in terms of interaction with the new economic and social dynamics and, more importantly, for creating the conditions for more active participation of citizens and consumers in the energy transition to full decarbonization. It is now important to increase the precision of the MS energy system modeling at the scale of cities. Since the period of implementation of the NECP started in January 2021, it is essential to outline the strategies, public policies, and measures to be implemented for smart cities and to contribute to the national targets of each MS.

To identify the relevant energy modeling tools, a search was made for review articles on models of energy systems using Google Scholar, as well as IEEE Xplore, and B-ON, a Portuguese online knowledge library. Search terms such as "energy system modeling review" and "energy modeling tool selection process" were used. In addition, other articles cited in these publications were also evaluated. Subsequently, there was a need to narrow the research carried out to specific properties of energy systems models using the same research methods, but with a focus on the modeling of energy demand, energy efficiency, demand-side management, and storage. A total of 39 review articles were evaluated [69-108].

In a second phase, the tools available online for modeling energy systems were selected. This selection includes only the tools that have been evaluated in the revised literature $[71,73,85,88,90,91,93,97,99]$, and which allow models of energy systems in general, and which are still available for download and with a significant number of users (more than 100 users), only possible to establish with complementary searches with the mentioned search engines and on the website of these modeling tools.

Regarding the open-source tools, which can already be applied to a wide range of problems, a recent investigation [93] compared these models with conventional models applied in energy systems and concluded that there is still a substantial performance gap.

The three most popular methodological approaches to energy system modeling are optimization, simulation, and equilibrium tools or models:

- Optimization tools: include the design optimization of endogenous systems;

- Simulation tools: provide the simulation of exogenously defined energy systems;

- Equilibrium tools or models: incorporate a larger econometric model of the society.

According to the research carried out, it was found that a wide range of computer tools allow users to model and analyze energy systems considering a geographic coverage ranging from cities to countries to help design paths for the energy transition, namely, their ambitious decarbonization. These models are frequently very distinct from each other and, thus, decision-makers and researchers must choose the most appropriate power system modeling tool, depending on the purpose and specific objectives of their analysis [74].

Therefore, as optimization tools are predominant within city energy systems analysis, difficulties in interpreting the results can arise due to their complexity that in some way can affect their accuracy. Several conclusions have already been identified regarding the characteristics of these tools, as an increase in the model complexity is not an assurance of higher accuracy $[90,109]$. Uncertainties and variations in the inputs used on the simulation models of low-carbon energy systems can also have a considerable impact on the performance of energy systems $[90,110]$, and top-down equilibrium models indicated substantial sensitivity when evaluating the integration of renewable energy sources and possibly need to be improved or to be used as a part of integrated mixed models $[90,111]$. 
Implementing the earlier described filtering to the final selection of modeling tools, 14 selected options are presented in Table 1.

Table 1. Tools considered for the analysis of this study.

\begin{tabular}{ccc}
\hline \multirow{2}{*}{ Tool } & \multicolumn{2}{c}{ Download Information } \\
\cline { 2 - 3 } & Weblink & Availability \\
\hline Calliope & {$[112]$} & Open-source \\
DER-CAM & {$[113]$} & Free to download \\
EnergyPLAN & {$[114]$} & Free to download \\
energyPRO & {$[115]$} & Commercial \\
Ficus & {$[116]$} & Open-source \\
HOMER Pro & {$[117]$} & Commercial \\
LEAP & {$[118]$} & Commercial/free for developing \\
MESSAGEix & {$[119]$} & countries and students \\
oemof & {$[120]$} & Open-source \\
RETScreen & {$[121]$} & Open-source \\
Temoa & {$[122]$} & Free to download \\
TIMES & {$[123]$} & Open-source \\
TRNSYS16 & {$[124]$} & Commercial \\
Urbs & {$[125]$} & Commercial \\
\hline
\end{tabular}

Figure 2 shows the definition of the criteria tree adopted in this study to support the selection of the modeling tool to promote energy efficiency, and its impact on a given energy system. The following operational characteristics that the modeling tool makes available were identified: the temporal resolution (minutes, hours, years), geographic coverage (city, regional, national, continental, or international), sectorial coverage (fossil resources, electricity, heat, and hydrogen), ability to include demand-response measures, and the type of access to the tool (open-source, free, or commercial). Regarding the assessment characteristics performed by the modeling tools, the considered options were energy efficiency, emissions, financing, and social impact in each energy system to be modeled.

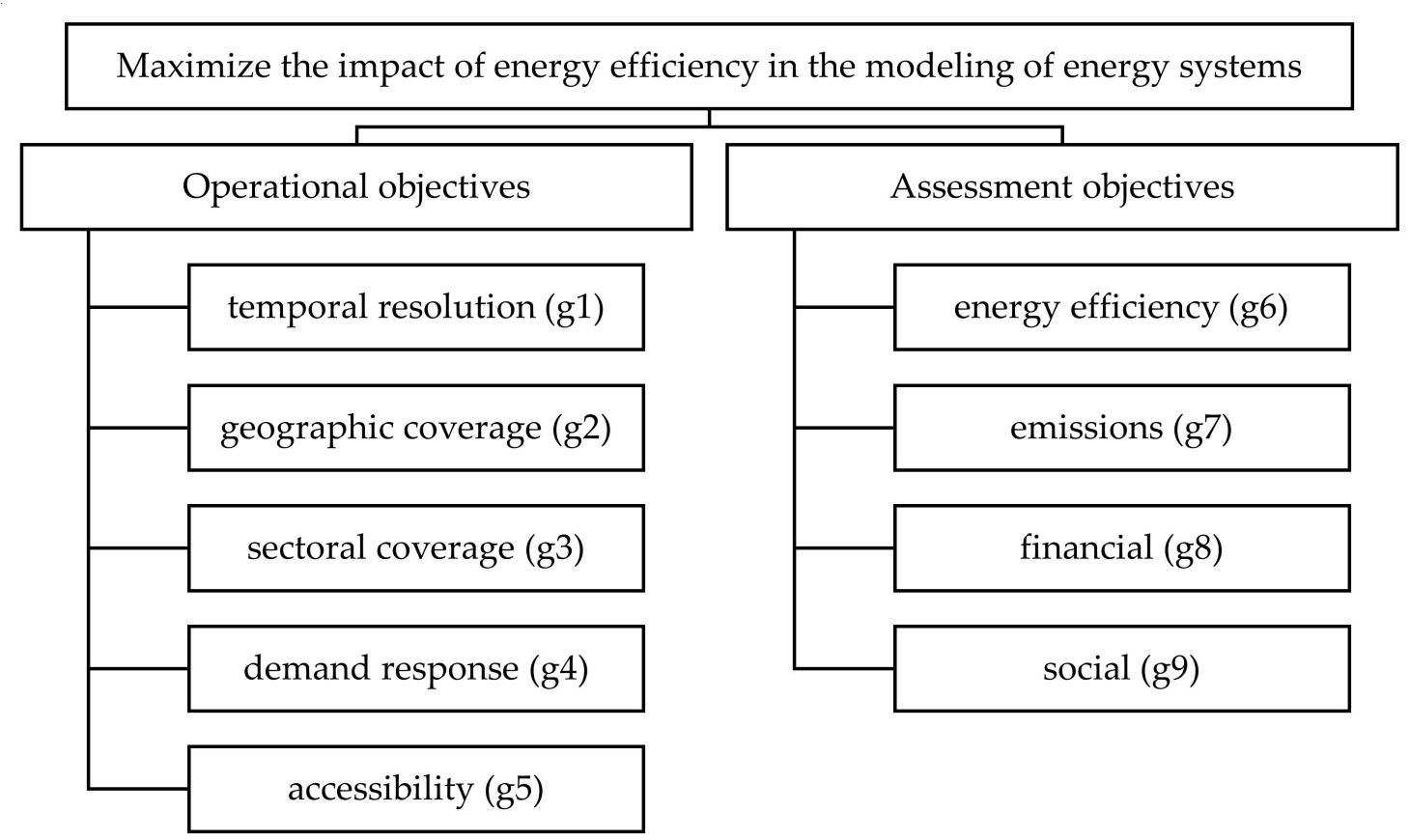

Figure 2. Definition of the criteria tree to support the decision. 
To finish the first part of this study, each of the nine criteria identified in Figure 2 was classified, as presented in Table 2, according to the adopted definition.

Table 2. Definition of each criterion used and its scales.

\begin{tabular}{|c|c|c|}
\hline \multirow{2}{*}{ Criteria } & \multicolumn{2}{|c|}{ Information } \\
\hline & Scales & Definition \\
\hline temporal resolution (g1) & 1 to 3 & $\begin{array}{l}\text { The tool allows simulating } \\
\text { minutes (1), hours (2), or } \\
\text { years (3). }\end{array}$ \\
\hline geographic coverage (g2) & 1 to 4 & $\begin{array}{l}\text { The tool allows simulating at } \\
\text { the city level (1), regional level } \\
\text { (2), national level (3), } \\
\text { continental or international } \\
\text { level (4). }\end{array}$ \\
\hline sectoral coverage (g3) & 1 to 4 & $\begin{array}{l}\text { The smallest number of sectors } \\
\text { covered by the tool, both on the } \\
\text { supply and demand side, up to } \\
\text { a maximum of } 4 \text { sectors. For } \\
\text { example, if a tool covers } 5 \\
\text { sectors on the supply side and } \\
\text { only } 2 \text { on the demand side, it } \\
\text { should have (2). }\end{array}$ \\
\hline demand response $(\mathrm{g} 4)$ & 0 or 1 & $\begin{array}{l}\text { The tool allows analyzing } \\
\text { demand response measures, if } \\
\text { yes (1) and no (0). }\end{array}$ \\
\hline accessibility (g5) & 0 to 2 & $\begin{array}{l}\text { The tool is paid }(0) \text {, free }(1) \text {, or } \\
\text { open-source }(2) \text {. }\end{array}$ \\
\hline energy efficiency (g6) & 0 or 1 & $\begin{array}{l}\text { The tool allows analyzing } \\
\text { energy efficiency as a result, if } \\
\text { yes }(1) \text { and no }(0) \text {. }\end{array}$ \\
\hline emissions (g7) & 0 or 1 & $\begin{array}{l}\text { The tool allows analyzing } \\
\text { energy emissions as a result, if } \\
\text { yes (1) and no (0). }\end{array}$ \\
\hline financial (g8) & 0 or 1 & $\begin{array}{l}\text { The tool allows analyzing } \\
\text { investments as a result, if yes (1) } \\
\text { and no }(0) \text {. }\end{array}$ \\
\hline social (g9) & 0 or 1 & $\begin{array}{l}\text { The tool allows analyzing social } \\
\text { impact as a result, if yes (1) and } \\
\text { no (0). }\end{array}$ \\
\hline
\end{tabular}

Multiple-criteria decision analysis (MCDA) methods are extensively used in public and private-sector decision-making on transport, energy, immigration, education, investment, environment, defense, etc. [126-128]. To define the alternatives, the characteristics of the multi-criterion methods were initially considered, namely:

- Ability to evaluate each alternative in absolute terms, and not just in comparison with others;

- Independence from scales, to allow the inclusion of impacts measured in different units and even impacts measured in qualitative terms.

It is also important that the adopted methodology can support a top-end decisionmaker, who may often not be an expert in energy modeling [129]. Such attributes indicate the use of the ELECTRE TRI method, a multiple-criteria decision method used in several 
knowledge areas [130-133], and whose methodology deals with the uncertainty of the parameters, as well as the subjective classification of alternatives by the decision-maker.

ELECTRE methods (ELimination Et Choix Traduisant la REalité) appeared in the 1960s [134] in France, as a way of evaluating various alternatives based on certain criteria. The methods are developed depending on the purpose that is to be achieved:

- Choice, to select the "best" alternative or a reduced set of "best" alternatives;

- Ranking, to rank the alternatives from the "best" one to the "worst" one;

- Sorting, to distribute alternatives into predefined categories.

Among the various methods, ELECTRE TRI was developed to respond to the classification problem [134], to organize it into several alternative categories.

In the present case, it was intended to apply the method to guide in the identification of an appropriate tool for a particular analysis of city energy systems for the energy efficiency objective, categorizing the modeling tools characteristics by the degree of criticality or relevance. This makes available to the decision-maker a tool that allows classifying the alternatives, ensuring that he guides the modeling of the energy sector within the parameters he considers most relevant.

The relative weights $(\mathrm{kj})$ of each criterion were distributed according to the importance allocated by the decision-maker, in this case, the authors. The importance coefficient (weight, kj) of criterion gk, which is always a positive number, was defined as the sum of all $\mathrm{kj}$ being equal to 1 . The following conditions were considered from this starting point:

(1) A quarter (25\%) of the total weight of the kj would be allocated according to the criterion that the tool allows analyzing energy efficiency as a result (g6), as the final use of the tool will be to model the contribution of energy efficiency for an energy system.

(2) For the same reason, but with less importance, it was considered that $15 \%$ would be the weight for the evaluation criterion concerning the tools that allow analyzing the impact of demand response measures (g4).

(3) Below the average, a weight of $10 \%$ was considered for the criterion that assessed whether the tool is paid or not (g5), as it will always be important to assess the initial costs for such academic exercise.

(4) As a less important criterion, the criterion with geographic coverage was considered, which would be $1 / 5$ of the criterion with the greatest weight, $5 \%$ (g2). This decision is supported by the previous analysis of the available tools, which practically all cover a city geographic scenario.

(5) The remaining criteria were given the average remaining value of $9 \%$, as they have the same relative importance.

In summary, Table 3 shows the weights attributed by the authors to the different defined criteria.

Table 3. Distribution of the weight of each criterion.

\begin{tabular}{cccccccccc}
\hline kj & g1 & g2 & g3 & g4 & g5 & g6 & g7 & g8 & g9 \\
\hline Weight & $9 \%$ & $5 \%$ & $9 \%$ & $15 \%$ & $10 \%$ & $25 \%$ & $9 \%$ & $9 \%$ & $9 \%$ \\
\hline
\end{tabular}

Based on the research and tests carried out about the use of the different tools, Table 4 lists the input data of the classification of each of the nine criteria for each of the 14 modeling tools. 
Table 4. Value of each criterion for each of the tools under analysis.

\begin{tabular}{cccccccccc}
\hline Tool & g1 & g2 & g3 & g4 & g5 & g6 & g7 & g8 & g9 \\
\hline Calliope & 3 & 4 & 4 & 1 & 2 & 0 & 0 & 1 & 0 \\
\hline DER-CAM & 3 & 1 & 4 & 1 & 1 & 0 & 0 & 1 & 0 \\
\hline EnergyPLAN & 2 & 4 & 3 & 0 & 1 & 1 & 1 & 1 & 1 \\
\hline energyPRO & 1 & 2 & 3 & 0 & 0 & 0 & 0 & 1 & 0 \\
\hline Ficus & 1 & 3 & 4 & 0 & 2 & 0 & 0 & 1 & 0 \\
\hline HOMER Pro & 1 & 1 & 1 & 0 & 0 & 0 & 0 & 1 & 0 \\
\hline LEAP & 3 & 3 & 4 & 1 & 1 & 1 & 1 & 1 & 1 \\
\hline MESSAGEix & 3 & 4 & 4 & 1 & 2 & 1 & 1 & 1 & 1 \\
\hline oemof & 3 & 4 & 4 & 1 & 2 & 1 & 1 & 1 & 1 \\
\hline RETScreen & 3 & 4 & 3 & 0 & 1 & 1 & 1 & 1 & 1 \\
\hline Temoa & 3 & 4 & 4 & 0 & 2 & 0 & 0 & 1 & 0 \\
\hline TIMES & 3 & 4 & 4 & 0 & 0 & 0 & 0 & 1 & 0 \\
\hline TRNSYS16 & 1 & 2 & 2 & 0 & 0 & 0 & 1 & 1 & 0 \\
\hline Urbs & 3 & 3 & 4 & 1 & 2 & 0 & 1 & 1 & 0 \\
\hline
\end{tabular}

\section{Results}

The evaluation process was carried out using the EXCEL calculation tool to implement the ELECTRE TRI methodology, starting with the introduction of performance data for 14 modeling tools according to the different criteria, profiles and associated thresholds, and weights. The cut-off level was restricted to the range [0.51, 0.67] since those limits correspond to a simple majority requirement and a two-thirds majority.

In this context of classification of modeling tools, the following categories of increasing importance were defined for consideration of the energy efficiency objective when choosing the most suitable tool: not a good choice (1), good choice (2), very good choice (3), and excellent choice (4). Through the methodology execution, the distribution of alternatives by the categories to a central scenario (without any restriction) was obtained and then conditioned by the restrictions related to the upper and lower limits of each limit of each profile, as presented in Figure 3.

The outputs show very balanced results. However, the results demonstrate that the LEAP, MESSAGEix, and oemof tools are very likely to be the best choices to achieve the proposed objective of assessing the real impact of energy efficiency on a given energy system, namely, on cities. Other hypotheses to consider are the Calliope, EnergyPLAN, RETScreen, and Urbs tools, which also reach the needs in a simple majority scenario [0.51].

Reflecting on the scenario of a two-thirds majority [0.67], the option for LEAP should be considered by students and researchers who do not intend to program the model in Python language (for example) and look for a friendlier interface. However, the MESSAGEix and oemof tools are two open-source tools that have remarkable potential for community development. It is important to mention that this evaluation is conditioned by the authors since other weights can be defined for the proposed criteria. 


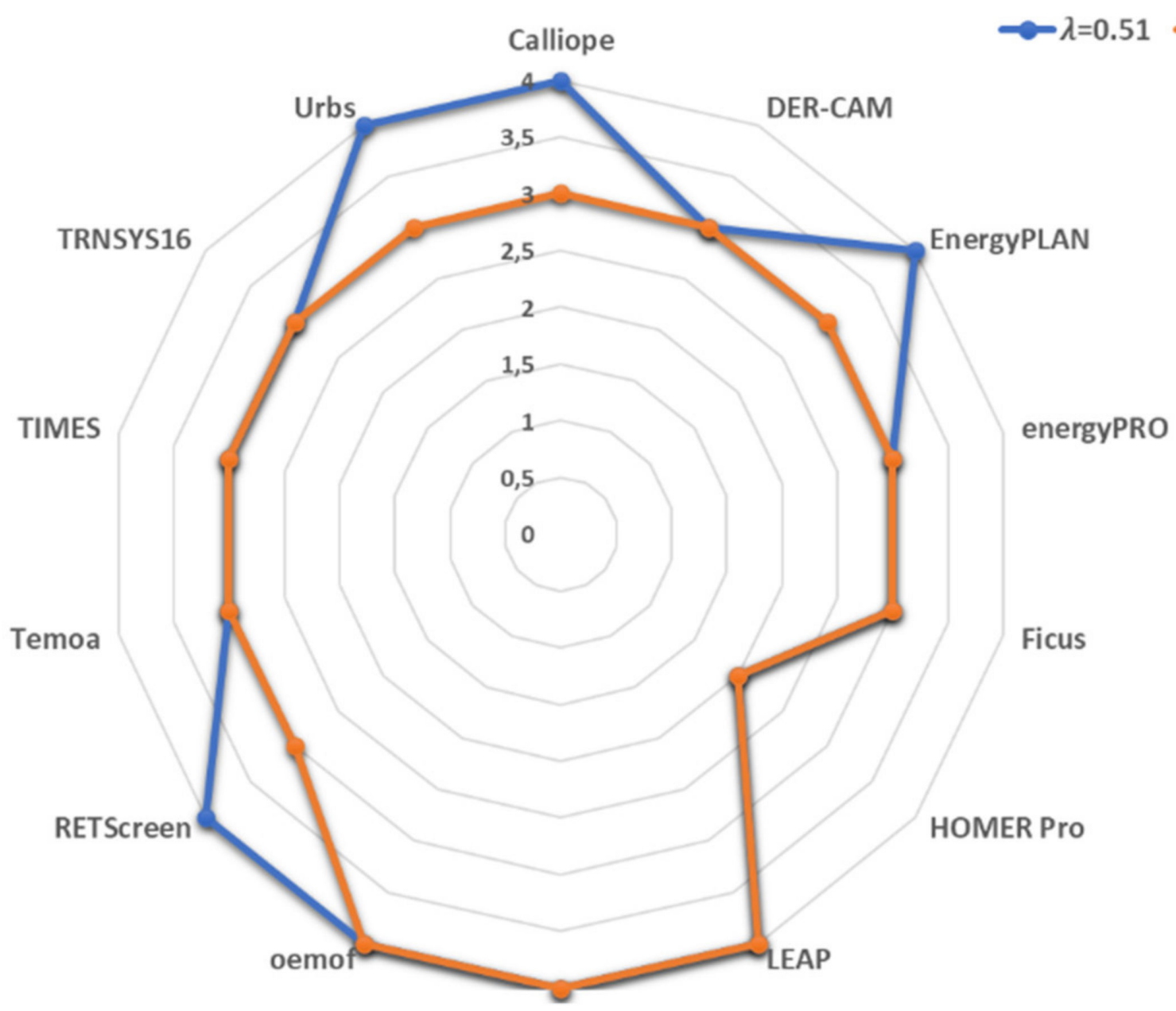

Figure 3. Results distribution by each tool.

\section{Conclusions}

Electrification is a key strategy to change from fossil to decarbonized resources, but energy efficiency should be the first fuel to be considered in this process due to its faster, more reliable, and cheaper implementation results. As electricity consumption will increase and since, in the short-to-medium term, not all electricity can be generated from renewable energy sources, it will be essential to ensure large-scale efficiency action on consumption in all sectors. However, it is important to move from intentions to action, and the cities' role is fundamental to achieving this goal. The European Community legislative framework based on the principle of "energy efficiency first" is not enough. Therefore, cities must become smart cities, and for that it is necessary to plan to the horizons 2030 and 2050, considering the impact of energy efficiency programs, in particular the implementation of Article 7 of the EED (Energy Efficiency Directive), which is undoubtedly the strongest European tool to promote energy efficiency.

The impact of the EED implementation will necessarily cause a significant transformation in the energy sector, in terms of energy generation, transmission, distribution, and consumption. If, on the one hand, the modeling tools contemplate the increase in energy efficiency in the technological evolution, as well as the efficient choice of the final consumer when purchasing new equipment, on the other hand, the impacts of political measures, such as the implementation of EED Article 7, are more complex to approach in current modeling tools. 
There are several modeling tools available to study the best way to achieve the objective of the energy sector carbon neutrality in the cities, even considering energy efficiency as the first and main measure to achieve this end. However, and without increasing the complexity of the models, the creation of sub-models and the use of different tools, when correctly applied, can generate results more consistent with reality.

The results of the current publication demonstrate that the LEAP, MESSAGEix, and oemof tools are the best options to achieve the proposed objective. It is possible to highlight LEAP, due to its friendlier work environment, as well as the possibility of programming in the MESSAGEix and oemof tools, which are open-source tools for the community. Combining the modeling tools with a multi-criteria decision approach to sorting input and output data, and the use of an energy balance Sankey Diagram, where energy efficiency should be seen as an energy vector, should be a future direction of research in the energy planning of smart cities.

Author Contributions: F.M.: conceptualization, methodology, data collection and assessment, writing—original draft, writing—review and editing. C.P.: conceptualization, writing—original draft, writing —review and editing. P.M.: conceptualization, writing—review and editing, supervision. A.T.d.A.: writing - review and editing, supervision. All authors have read and agreed to the published version of the manuscript.

Funding: Support for this research was provided by OE—national funds of FCT/MCTES (PIDDAC) under the project UID/EEA/00048/2019.

Conflicts of Interest: The authors declare that they have no known competing financial interests or personal relationships that could have appeared to influence the work reported in this paper.

\section{References}

1. British Standards Institution (BSI). The Role of Standards in Smart Cities. Available online: https://www.bsigroup.com/ LocalFiles/en-GB/smart-cities/resources/The-Role-of-Standards-in-Smart-Cities-Issue-2-August-2014.pdf (accessed on 27 March 2021).

2. Chourabi, H.; Nam, T.; Walker, S.; Gil-Garcia, J.R.; Mellouli, S.; Nahon, K.; Pardo, T.A.; Scholl, H.J. Understanding smart cities: An integrative framework. In Proceedings of the 2012 45th Hawaii International Conference on System Sciences, Kauai, HI, USA, 4-7 January 2012; pp. 2289-2297.

3. United Nations; Department of Economic and Social Affairs; Population Division. World Urbanization Prospects-The 2018 Revision (ST/ESA/SER.A/420); United Nations: New York, NY, USA, 2019; ISBN 978-92-1-148319-2.

4. United Nations; Department of Economic and Social Affairs; Population Division. The World's Cities in 2018-Data Booklet (ST/ESA/ SER.A/417); United Nations: New York, NY, USA, 2018.

5. United Nations; Department of Economic and Social Affairs; Population Division. The World's Cities in 2016-Data Booklet (ST/ESA/SER.A/392); United Nations: New York, NY, USA, 2016; ISBN 978-92-1-151549-7.

6. United Nations. United Nations Sustainable Development Goals. Available online: https:/ / www.un.org/sustainabledevelopment/ (accessed on 2 April 2021).

7. United Nations SDG11: Make Cities Inclusive, Safe, Resilient and Sustainable. Available online: https://www.un.org/ sustainabledevelopment/cities/ (accessed on 2 April 2021).

8. Unted Nations. The New Urban Agenda. Available online: https://habitat3.org/the-new-urban-agenda/ (accessed on 2 April 2021).

9. Schraven, D.; Joss, S.; de Jong, M. Past, present, future: Engagement with sustainable urban development through 35 city labels in the scientific literature 1990-2019. J. Clean. Prod. 2021, 292, 125924. [CrossRef]

10. Bigano, A.; Ortiz, R.; Markandya, A.; Menichetti, E.; Pierfederici, R. The Linkages between Energy Efficiency and Security of Energy Supply in Europe. Handb. Sustain. Energy 2010. [CrossRef]

11. Allcott, H.; Greenstone, M. Measuring the Welfare Effects of Residential Energy Efficiency Programs; Working Paper Series; National Bureau of Economic Research: Boston, MA, USA, 2017.

12. Reinman, S.L. Intergovernmental Panel on Climate Change (IPCC). Ref. Rev. 2012, 26, 41-42. [CrossRef]

13. IEA-International Energy Agency. Energy Efficiency 2020. Available online: https://www.iea.org/reports/energy-efficiency-20 20 (accessed on 14 April 2021).

14. Taylor, K. Energy Efficiency Must Apply across All Renewables, EU Commission Says. 2021. Available online: www.euractiv.com (accessed on 14 April 2021). 
15. Directive 2012/27/EU of the European Parliament and of the Council of 25 October 2012 on energy efficiency, amending Directives 2009/125/EC and 2010/30/EU and repealing Directives 2004/8/EC and 2006/32. Off. J. L 2012, 315, 1-56.

16. Bertoldi, P.; Mosconi, R. Do energy efficiency policies save energy? A new approach based on energy policy indicators (in the EU Member States). Energy Policy 2020, 139, 111320. [CrossRef]

17. Directive 2010/31/EU of the European Parliament and of the Council of 19 May 2010 on the energy performance of buildings (recast). Off. J. Eur. Union 2010, 153, 35.

18. Directive 2009/125/EC of the European Parliament and of the Council of 21 October 2009, establishing a framework for the setting of ecodesign requirements for energyrelated products (recast). Off. J. Eur. Commun. 2009, 285, 35.

19. European Commission. Regulation (EU) 2017/1369 of the European Parliament and of the Council of 4 July 2017 Setting a Framework for Energy Labelling and Repealing Directive 2010/30/EU. 2017. Available online: https:/ / eur-lex.europa.eu/legalcontent/EN/TXT/?uri=CELEX\%3A02017R1369-20210501 (accessed on 14 July 2021).

20. European Commission. Regulation (EU) 2019/631 of the European Parliament and of the Council of 17 April 2019 Setting CO2 Emission Performance Standards for New Passenger Cars and for New Light Commercial Vehicles and Repealing Regulations (EC) No 443/2009 and (EU) No 510/2011. 2019. Available online: https:/ / eur-lex.europa.eu/legal-content/EN/TXT/HTML/ ?uri=CELEX:32019R0631\&from=EN (accessed on 14 July 2021).

21. United Nations. The Paris Agreement; United Nations: New York, NY, USA, 2015.

22. IEA-International Energy Agency. World Energy Outlook 2021. Available online: https://www.iea.org/reports/world-energyoutlook-2021 (accessed on 20 October 2021).

23. Governing the Dark Side of Renewable Energy: A Typology of Global Displacements—ScienceDirect. Available online: https: / /www.sciencedirect.com/science/article/abs/pii/S2214629620304771 (accessed on 20 October 2021).

24. Aditya, L. Financing Energy Efficiency, Part 1: Revolving Funds; World Bank: Washington, DC, USA, 2018.

25. Wu, Y.; Singh, J.; Tucker, D.K. Financing Energy Efficiency, Part 2: Credit Lines; World Bank: Washington, DC, USA, 2018.

26. Electrification of Transport and Residential Heating Sectors in Support of Renewable Penetration: Scenarios for the Italian Energy System I Elsevier Enhanced Reader. Available online: https: / / reader.elsevier.com $/$ reader / sd / pii $/$ S0360544220301699?token= 2173A4D481B019DDD9559937B57BCBA0CDBF4E806902730B223621DFC2F55833DF95833B50F3AE4B9D058A6F91AC8E42\& originRegion=eu-west-1\&originCreation=20211020115453 (accessed on 20 October 2021).

27. Dely, K.; Joubert, J.; Cities, P.S.E. About HeatNet NWE. 2019. Available online: https://www.nweurope.eu/media/8624/wpt3 _d13_heatnet-procurement-guide_v2.pdf (accessed on 13 November 2021).

28. Mora, L.; Deakin, M. The first two decades of research on smart city development. In Untangling Smart Cities; Mora, L., Deakin, M., Eds.; Elsevier: Amsterdam, The Netherlands, 2019; pp. 57-87, ISBN 978-0-12-815477-9.

29. Sharifi, A. A typology of smart city assessment tools and indicator sets. Sustain. Cities Soc. 2020, 53, 101936. [CrossRef]

30. Akande, A.; Cabral, P.; Casteleyn, S. Assessing the gap between technology and the environmental sustainability of european cities. Inf. Syst. Front. 2019, 21, 581-604. [CrossRef]

31. Nam, T.; Pardo, T.A. Conceptualizing smart city with dimensions of technology, people, and institutions. In Proceedings of the 12th Annual International Conference on Digital Government Research; New York, NY, USA, 12 June 2011, University of Maryland: College Park, MD, USA, 2011; pp. 282-291.

32. Ojo, A.; Dzhusupova, Z.; Curry, E. Exploring the nature of the smart cities research landscape. In Public Administration and Information Technology; Springer: Berlin/Heidelberg, Germany, 2016; Volume 11, pp. 23-47.

33. Hollands, R.G. Will the real smart city please stand up? Intelligent, progressive or entrepreneurial? City 2008, 12, 303-320. [CrossRef]

34. Höjer, M.; Wangel, J. Smart sustainable cities: Definition and challenges. In ICT Innovations for Sustainability. Advances in Intelligent Systems and Computing; Hilty, L.M., Aebischer, B., Eds.; Advances in Intelligent Systems and Computing; Springer: Berlin/Heidelberg, Germany, 2015; Volume 310, pp. 333-349. ISBN 978-3-319-09227-0.

35. Li, Y.; Commenges, H.; Bordignon, F.; Bonhomme, C.; Deroubaix, J.-F. The Tianjin Eco-City model in the academic literature on urban sustainability. J. Clean. Prod. 2019, 213, 59-74. [CrossRef]

36. de Jong, M.; Joss, S.; Schraven, D.; Zhan, C.; Weijnen, M. Sustainable-smart-resilient-low carbon-eco-knowledge cities; making sense of a multitude of concepts promoting sustainable urbanization. J. Clean. Prod. 2015, 109, 25-38. [CrossRef]

37. Al-Nasrawi, S.; Adams, C.; El-Zaart, A. A conceptual multidimensional model for assessing smart sustainable cities. J. Inf. Syst. Technol. Manag. 2015, 12, 541-558. [CrossRef]

38. Bibri, S.E.; Krogstie, J. Smart sustainable cities of the future: An extensive interdisciplinary literature review. Sustain. Cities Soc. 2017, 31, 183-212. [CrossRef]

39. O'Dwyer, E.; Pan, I.; Acha, S.; Shah, N. Smart energy systems for sustainable smart cities: Current developments, trends and future directions. Appl. Energy 2019, 237, 581-597. [CrossRef]

40. Silva, B.N.; Khan, M.; Han, K. Towards sustainable smart cities: A review of trends, architectures, components, and open challenges in smart cities. Sustain. Cities Soc. 2018, 38, 697-713. [CrossRef]

41. Patrão, C.; Moura, P.; de Almeida, A.T. Review of smart city assessment tools. Smart Cities 2020, 3, 1117-1132. [CrossRef] 
42. Wang, M.-H.; Ho, Y.-S.; Fu, H.-Z. Global performance and development on sustainable city based on natural science and social science research: A bibliometric analysis. Sci. Total Environ. 2019, 666, 1245-1254. [CrossRef]

43. United for Smart Sustainable Cities (U4SSC). Available online: https://www.itu.int:443/en/ITU-T/ssc/united/Pages / default. aspx (accessed on 18 March 2021).

44. ISO-International Standardization Organization. ISO 37122:2019-Sustainable Cities and Communities-Indicators for Smart Cities; International Standardization Organization: Geneva, Switzerland, 2019.

45. Ahvenniemi, H.; Huovila, A.; Pinto-Seppä, I.; Airaksinen, M. What are the differences between sustainable and smart cities? Cities 2017, 60, 234-245. [CrossRef]

46. Iqbal, A.; Olariu, S. A survey of enabling technologies for smart communities. Smart Cities 2021, 4, 54-77. [CrossRef]

47. Meijer, A.; Bolívar, M.P.R. Governing the smart city: A review of the literature on smart urban governance. Int. Rev. Adm. Sci. 2016, 82, 392-408. [CrossRef]

48. Sharifi, A. A critical review of selected smart city assessment tools and indicator sets. J. Clean. Prod. 2019, 233, 1269-1283. [CrossRef]

49. Mora, L.; Deakin, M.; Reid, A.; Angelidou, M. How to overcome the dichotomous nature of smart city research: Proposed methodology and results of a pilot study. J. Urban Technol. 2019, 26, 89-128. [CrossRef]

50. European Commission. What Are Smart Cities? Available online: https://ec.europa.eu/info/eu-regional-and-urbandevelopment/topics/cities-and-urban-development/city-initiatives/smart-cities_en (accessed on 4 August 2020).

51. IEEE. IEEE Smart Cities. Available online: https:/ / smartcities.ieee.org/ (accessed on 12 June 2021).

52. United Nations. Smart Cities and Infrastructure Report of the Secretary-General Economic and Social Council; United Nations-Economic and Social Council, Commission on Science and Technology for Development: New York, NY, USA, 2016; p. 18.

53. ITU. Y.4901/L.1601-Key Performance Indicators Related to the Use of Information and Communication Technology in Smart Sustainable Cities; International Telecommunication Union: Geneva, Switzerland, 2016.

54. United Nations. Sustainable Development Goal 11+-Make Cities and Human Settlements Inclusive, Safe, Resilient and Sustainable; United Nations: New York, NY, USA, 2019.

55. Giffinger, R.; Fertner, C.; Kramar, H.; Kalasek, R.; Pichler-Milanović, N.; Meijers, E. Smart Cities-Ranking of European Medium-Sized Cities; Centre of Regional Science, Vienna University of Technology: Vienna, Austria, 2007; p. 28.

56. Lombardi, P.; Giordano, S.; Farouh, H.; Yousef, W. Modelling the smart city performance. Innov. Eur. J. Soc. Sci. Res. 2012, 25, 137-149. [CrossRef]

57. Barrionuevo, J.; Berrone, P.; Ricart, J. Smart cities, sustainable progress: Opportunities for urban development. IESE Insight 2012, 14, 50-57. [CrossRef]

58. Alawadhi, S.; Aldama-Nalda, A.; Chourabi, H.; Gil-Garcia, J.R.; Leung, S.; Mellouli, S.; Nam, T.; Pardo, T.A.; Scholl, H.J.; Walker, S. Building understanding of smart city initiatives. In Proceedings of the Electronic Government; Scholl, H.J., Janssen, M., Wimmer, M.A., Moe, C.E., Flak, L.S., Eds.; Springer: Berlin/Heidelberg, Germany, 2012; pp. 40-53.

59. Koca, G.; Egilmez, O.; Akcakaya, O. Evaluation of the smart city: Applying the dematel technique. Telemat. Inform. 2021, 62, 101625. [CrossRef]

60. Toli, A.M.; Murtagh, N. The concept of sustainability in smart city definitions. Front. Built Environ. 2020, 6, 77. [CrossRef]

61. Albino, V.; Berardi, U.; Dangelico, R.M. Smart cities: Definitions, dimensions, performance, and initiatives. J. Urban Technol. 2015, 22, 3-21. [CrossRef]

62. Eremia, M.; Toma, L.; Sanduleac, M. The smart city concept in the 21st century. Procedia Eng. 2017, 181, 12-19. [CrossRef]

63. Eger, J. Smart Growth, Smart Cities, and the Crisis at the Pump A Worldwide Phenomenon. I-WAYS-J. E-Gov. Policy Regul. 2009, 32, 47-53. [CrossRef]

64. Kourtit, K.; Nijkamp, P.; Arribas, D. Smart cities in perspective-A comparative European study by means of self-organizing maps. Innov. Eur. J. Soc. Sci. Res. 2012, 25, 229-246. [CrossRef]

65. Mahizhnan, A. Smart cities: The Singapore case. Cities 1999, 16, 13-18. [CrossRef]

66. Akcin, M.; Kaygusuz, A.; Karabiber, A.; Alagoz, S.; Alagoz, B.B.; Keles, C. Opportunities for energy efficiency in smart cities. In Proceedings of the 2016 4th International Istanbul Smart Grid Congress and Fair (ICSG), Istanbul, Turkey, 20-21 April 2016; pp. 1-5.

67. European Commission National Energy and Climate Plans (NECPs). Available online: https://ec.europa.eu/energy/topics/ energy-strategy/national-energy-climate-plans_en (accessed on 4 August 2021).

68. Lappas, M. Paving the Way for Decarbonization and Electrification: 31. Ph.D. Thesis, Harvard University, Cambridge, MA, USA, 2021.

69. Allegrini, J.; Orehounig, K.; Mavromatidis, G.; Ruesch, F.; Dorer, V.; Evins, R. A review of modelling approaches and tools for the simulation of district-scale energy systems. Renew. Sustain. Energy Rev. 2015, 52, 1391-1404. [CrossRef]

70. Bhattacharyya, S.C.; Timilsina, G.R. A review of energy system models. Int. J. Energy Sect. Manag. 2010, 4, 494-518. [CrossRef]

71. Chang, M.; Thellufsen, J.Z.; Zakeri, B.; Pickering, B.; Pfenninger, S.; Lund, H.; Østergaard, P.A. Trends in tools and approaches for modelling the energy transition. Appl. Energy 2021, 290, 116731. [CrossRef]

72. Connolly, D.; Lund, H.; Mathiesen, B.V.; Leahy, M. A review of computer tools for analysing the integration of renewable energy into various energy systems. Appl. Energy 2010, 87, 1059-1082. [CrossRef] 
73. Dagoumas, A.S.; Koltsaklis, N.E. Review of models for integrating renewable energy in the generation expansion planning. Appl. Energy 2019, 242, 1573-1587. [CrossRef]

74. Després, J.; Hadjsaid, N.; Criqui, P.; Noirot, I. Modelling the impacts of variable renewable sources on the power sector: Reconsidering the typology of energy modelling tools. Energy 2015, 80, 486-495. [CrossRef]

75. Fathima, A.H.; Palanisamy, K. Optimization in microgrids with hybrid energy systems-A review. Renew. Sustain. Energy Rev. 2015, 45, 431-446. [CrossRef]

76. Foley, A.M.; Ó Gallachóir, B.P.; Hur, J.; Baldick, R.; McKeogh, E.J. A strategic review of electricity systems models. Energy 2010, 35, 4522-4530. [CrossRef]

77. Gu, W.; Wu, Z.; Bo, R.; Liu, W.; Zhou, G.; Chen, W.; Wu, Z. Modeling, planning and optimal energy management of combined cooling, heating and power microgrid: A review. Int. J. Electr. Power Energy Syst. 2014, 54, 26-37. [CrossRef]

78. Hall, L.M.H.; Buckley, A.R. A review of energy systems models in the UK: Prevalent usage and categorisation. Appl. Energy 2016, 169, 607-628. [CrossRef]

79. Harish, V.S.K.V.; Kumar, A. A review on modeling and simulation of building energy systems. Renew. Sustain. Energy Rev. 2016, 56, 1272-1292. [CrossRef]

80. Herbst, A.; Toro, F.; Reitze, F.; Jochem, E. Introduction to energy systems modelling. Swiss J. Econ. Stat. 2012, 148, 111-135. [CrossRef]

81. Hiremath, R.B.; Shikha, S.; Ravindranath, N.H. Decentralized energy planning; modeling and application-A review. Renew. Sustain. Energy Rev. 2007, 11, 729-752. [CrossRef]

82. Jebaraj, S.; Iniyan, S. A review of energy models. Renew. Sustain. Energy Rev. 2006, 10, 281-311. [CrossRef]

83. Jiang, X.S.; Jing, Z.X.; Li, Y.Z.; Wu, Q.H.; Tang, W.H. Modelling and operation optimization of an integrated energy based direct district water-heating system. Energy 2014, 64, 375-388. [CrossRef]

84. Kampelis, N.; Tsekeri, E.; Kolokotsa, D.; Kalaitzakis, K.; Isidori, D.; Cristalli, C. Development of demand response energy management optimization at building and district levels using genetic algorithm and artificial neural network modelling power predictions. Energies 2018, 11, 3012. [CrossRef]

85. Klemm, C.; Vennemann, P. Modeling and optimization of multi-energy systems in mixed-use districts: A review of existing methods and approaches. Renew. Sustain. Energy Rev. 2021, 135, 110206. [CrossRef]

86. Li, L.; Mu, H.; Gao, W.; Li, M. Optimization and analysis of CCHP system based on energy loads coupling of residential and office buildings. Appl. Energy 2014, 136, 206-216. [CrossRef]

87. Liu, X.; Mancarella, P. Modelling, assessment and Sankey diagrams of integrated electricity-heat-gas networks in multi-vector district energy systems. Appl. Energy 2016, 167, 336-352. [CrossRef]

88. Lopion, P.; Markewitz, P.; Robinius, M.; Stolten, D. A review of current challenges and trends in energy systems modeling. Renew. Sustain. Energy Rev. 2018, 96, 156-166. [CrossRef]

89. Luna-Rubio, R.; Trejo-Perea, M.; Vargas-Vázquez, D.; Ríos-Moreno, G.J. Optimal sizing of renewable hybrids energy systems: A review of methodologies. Sol. Energy 2012, 86, 1077-1088. [CrossRef]

90. Lund, H.; Thellufsen, J.Z.; Østergaard, P.A.; Sorknæs, P.; Skov, I.R.; Mathiesen, B.V. EnergyPLAN-Advanced analysis of smart energy systems. Smart Energy 2021, 1, 100007. [CrossRef]

91. Lyden, A.; Pepper, R.; Tuohy, P.G. A modelling tool selection process for planning of community scale energy systems including storage and demand side management. Sustain. Cities Soc. 2018, 39, 674-688. [CrossRef]

92. Mancarella, P. MES (multi-energy systems): An overview of concepts and evaluation models. Energy 2014, 65, 1-17. [CrossRef]

93. Oberle, S.; Elsland, R. Are open access models able to assess today's energy scenarios? Energy Strategy Rev. 2019, 26, 100396. [CrossRef]

94. Olsthoorn, D.; Haghighat, F.; Mirzaei, P.A. Integration of storage and renewable energy into district heating systems: A review of modelling and optimization. Sol. Energy 2016, 136, 49-64. [CrossRef]

95. Orehounig, K.; Evins, R.; Dorer, V. Integration of decentralized energy systems in neighbourhoods using the energy hub approach. Appl. Energy 2015, 154, 277-289. [CrossRef]

96. Pfenninger, S.; DeCarolis, J.; Hirth, L.; Quoilin, S.; Staffell, I. The importance of open data and software: Is energy research lagging behind? Energy Policy 2017, 101, 211-215. [CrossRef]

97. Pfenninger, S.; Hawkes, A.; Keirstead, J. Energy systems modeling for twenty-first century energy challenges. Renew. Sustain. Energy Rev. 2014, 33, 74-86. [CrossRef]

98. Powell, K.M.; Sriprasad, A.; Cole, W.J.; Edgar, T.F. Heating, cooling, and electrical load forecasting for a large-scale district energy system. Energy 2014, 74, 877-885. [CrossRef]

99. Ringkjøb, H.-K.; Haugan, P.M.; Solbrekke, I.M. A review of modelling tools for energy and electricity systems with large shares of variable renewables. Renew. Sustain. Energy Rev. 2018, 96, 440-459. [CrossRef]

100. Stein, E.W. A comprehensive multi-criteria model to rank electric energy production technologies. Renew. Sustain. Energy Rev. 2013, 22, 640-654. [CrossRef]

101. Subramanian, A.S.R.; Gundersen, T.; Adams, T.A. Modeling and simulation of energy systems: A review. Processes 2018, 6, 238. [CrossRef]

102. Suganthi, L.; Samuel, A.A. Energy models for demand forecasting-A review. Renew. Sustain. Energy Rev. 2012, 16, 1223-1240. [CrossRef] 
103. Swan, L.G.; Ugursal, V.I. Modeling of end-use energy consumption in the residential sector: A review of modeling techniques. Renew. Sustain. Energy Rev. 2009, 13, 1819-1835. [CrossRef]

104. van Beuzekom, I.; Gibescu, M.; Slootweg, J.G. A review of multi-energy system planning and optimization tools for sustainable urban development. In Proceedings of the 2015 IEEE Eindhoven PowerTech, Eindhoven, The Netherlands, 29 June-2 July 2015 ; pp. 1-7.

105. van Vuuren, D.P.; Hoogwijk, M.; Barker, T.; Riahi, K.; Boeters, S.; Chateau, J.; Scrieciu, S.; van Vliet, J.; Masui, T.; Blok, K.; et al. Comparison of top-down and bottom-up estimates of sectoral and regional greenhouse gas emission reduction potentials. Energy Policy 2009, 37, 5125-5139. [CrossRef]

106. Wang, H.; Yin, W.; Abdollahi, E.; Lahdelma, R.; Jiao, W. Modelling and optimization of CHP based district heating system with renewable energy production and energy storage. Appl. Energy 2015, 159, 401-421. [CrossRef]

107. Weijermars, R.; Taylor, P.; Bahn, O.; Das, S.R.; Wei, Y.-M. Review of models and actors in energy mix optimization-Can leader visions and decisions align with optimum model strategies for our future energy systems? Energy Strategy Rev. 2012, 1, 5-18. [CrossRef]

108. Xu, X.; Jia, H.; Chiang, H.-D.; Yu, D.C.; Wang, D. Dynamic modeling and interaction of hybrid natural gas and electricity supply system in microgrid. IEEE Trans. Power Syst. 2015, 30, 1212-1221. [CrossRef]

109. Priesmann, J.; Nolting, L.; Praktiknjo, A. Are complex energy system models more accurate? An intra-model comparison of power system optimization models. Appl. Energy 2019, 255, 113783. [CrossRef]

110. Pilpola, S.; Lund, P.D. Analyzing the effects of uncertainties on the modelling of low-carbon energy system pathways. Energy 2020, 201, 117652. [CrossRef]

111. Tapia-Ahumada, K.; Octaviano, C.; Rausch, S.; Pérez-Arriaga, I. Modeling intermittent renewable electricity technologies in general equilibrium models. Econ. Model. 2015, 51, 242-262. [CrossRef]

112. Pfenninger, S.; Pickering, B. Calliope: A multi-scale energy systems modelling framework. J. Open Source Softw. $2018,3,825$. [CrossRef]

113. DER-CAM I Grid Integration Group. Available online: https://gridintegration.lbl.gov/der-cam (accessed on 19 August 2021).

114. EnergyPLAN. Available online: https:/ / www.energyplan.eu/ (accessed on 19 August 2021).

115. EnergyPRO. Available online: https:/ / www.energysoft.com/ (accessed on 19 August 2021).

116. Ficus: A (Mixed Integer) Linear Optimisation Model for Local Energy Systems-Ficus 0.1 Documentation. Available online: https: / / ficus.readthedocs.io/en/latest/index.html (accessed on 6 September 2021).

117. HOMER Pro-Microgrid Software for Designing Optimized Hybrid Microgrids. Available online: https://www.homerenergy. com/products/pro/index.html (accessed on 6 September 2021).

118. LEAP. Available online: https:/ / leap.sei.org/default.asp?action=introduction (accessed on 6 September 2021).

119. The MESSAGEix Framework-MESSAGEix 3.3.0 Documentation. Available online: https://docs.messageix.org/en/stable/ (accessed on 6 September 2021).

120. A Modular Open Source Framework to Model Energy Supply Systems. Available online: https://oemof.org/ (accessed on 6 September 2021).

121. Natural Resources Canada. Retscreen. Available online: https://www.nrcan.gc.ca/maps-tools-and-publications/tools/ modelling-tools/retscreen/7465 (accessed on 6 September 2021).

122. DeCarolis, J.; Hunter, K.; Li, B.; Sreepathi, S. Temoa (Tools for Energy Model Optimization and Analysis), Model Item, OpenGMS 2019. Available online: https://geomodeling.njnu.edu.cn/modelItem/fc6bdfc5-ec1e-47bc-9b33-86417257c5aa (accessed on 6 September 2021).

123. IEA-ETSAP / Times. Available online: https:/ / iea-etsap.org/index.php/etsap-tools/model-generators/times (accessed on 6 September 2021).

124. TRNSYS-Official Website. Available online: https://sel.me.wisc.edu/trnsys/demos/demo.html (accessed on 6 September 2021).

125. Urbs: A Linear Optimisation Model for Distributed Energy Systems-Urbs 1.0.0 Documentation. Available online: https: / / urbs.readthedocs.io/en/latest/ (accessed on 6 September 2021).

126. Gregory, R.; Failing, L.; Harstone, M.; Long, G.; McDaniels, T.; Ohlson, D. Structured Decision Making: A Practical Guide to Environmental Management Choices; John Wiley \& Sons: Hoboken, NJ, USA, 2012; ISBN 978-1-4443-9853-3.

127. Devlin, N.; Sussex, J. Incorporating Multiple Criteria in HTA: Methods and Processes; Office of Health Economics: London, UK, 2011.

128. Great Britain; Department for Communities and Local Government. Multi-Criteria Analysis: A Manual; Communities and Local Government: Wetherby, UK, 2009; ISBN 978-1-4098-1023-0.

129. Antunes, C.H.; Dias, L.; Dantas, G.; Mathias, J.; Zamboni, L. An application of soft systems methodology in the evaluation of policies and incentive actions to promote technological innovations in the electricity sector. Energy Procedia 2016, 106, 258-278. [CrossRef]

130. Figueira, J.; Greco, S.; Ehrgott, M. Multiple Criteria Decision Analysis: State of the Art Surveys; Springer Science \& Business Media: Berlin/Heidelberg, Germany, 2005; ISBN 978-0-387-23067-2.

131. Neves, L.P.; Martins, A.G.; Antunes, C.H.; Dias, L.C. A multi-criteria decision approach to sorting actions for promoting energy efficiency. Energy Policy 2008, 36, 2351-2363. [CrossRef]

132. Dias, L.C.; Antunes, C.H.; Dantas, G.; de Castro, N.; Zamboni, L. A multi-criteria approach to sort and rank policies based on Delphi qualitative assessments and ELECTRE TRI: The case of smart grids in Brazil. Omega 2018, 76, 100-111. [CrossRef] 
133. Bernardo, H.; Gaspar, A.; Antunes, C.H. An application of a multi-criteria decision support system to assess energy performance of school buildings. Energy Procedia 2017, 122, 667-672. [CrossRef]

134. Roy, B. The outranking approach and the foundations of electre methods. Theory Decis. 1991, 31, 49-73. [CrossRef] 